\title{
FINANCIAL PERFORMANCE ANALYSIS FOR RETURN ON ASSETS WITH A MULTIPLE LINIER REGRESSION APPROACH
}

\author{
Hendra H. Dukalang ${ }^{1 *}$ \\ ${ }^{1}$ Jurusan Perbankan Syariah, IAIN Sultan Amai Gorontalo. Kabupaten Gorontalo 96210, Indonesia \\ *Penulis Korespondensi.Email: hendra.statistika@iaingorontalo.ac.id
}

\begin{abstract}
Abstrak
Penelitian ini bertujuan untuk memodelkan faktor-faktor yang mempengaruhi kinerja keuangan Bank Muammalat, yakni Capital Adequacy Ratio (CAR), Kualitas Aktiva Produktif (KAP), Beban Operasional terhadap Pendapatan Operasional (BOPO), dan Financing to Deposit Ratio (FDR) Terhadap Return on Assets (ROA. Penelitin ini menggunakan data sekunder yang diambil berdasarkan periode waktu (time series). Teknik analisis dalam penelitian ini menggunakan regresi linier berganda dengan menggunakan software SPSS versi 20 dan Microsoft Office Excel 2010. Hasil penelitian ini menunjukkan bahwa secara parsial CAR dan KAP tidak berpengaruh secara signifikan terhadap Return on Assets, Sedangkan BOPO dan FDR secara parsial berpengaruh secara signifikan terhadap Return on Assets. Secara simultan keempatt variable tersebut berpengaruh ignifikan terhadap Return on Assets pada PT Bank Muamalat Indonesia. Berdasarkan hasil uji Koefisien Determinasi nilai Adjusted $R$ Square $\left(\mathrm{R}^{2}\right)$ adalah sebesar $99,00 \%$ hal ini berarti besarnya Return on Assets dapat dipengaruhi dan dijelaskan oleh variabel CAR, KAP, BOPO, dan FDR, sedangkan sebesar $1 \%$ sisanya dijelaskan oleh variabel yang tidak diteliti dalam penelitian ini.
\end{abstract}

Kata Kunci: Regresi Linier Berganda; CAR; KAP; BOPO; FDR; ROA

\begin{abstract}
This study aims to model the factors that affect the financial performance of Bank Muammalat, including Capital Adequacy Ratio (CAR), Earning Asset Quality (KAP), Operational Expenses to Operating Income (BOPO), and Financing to Deposit Ratio (FDR) to Return on Assets. (ROA) This research uses secondary data taken based on time series. The analysis technique in this study uses multiple linear regression using SPSS software version 20 and Microsoft Office Excel 2010. The results of this study indicate that partially the CAR and KAP partially do not have a significant effect on Return On. Assets, while Operational Expenses to BOPO and FDR partially have a significant effect on Return on Assets. Simultaneously, these four variables have a significant effect on Return on Assets at PT Bank Muamalat Indonesia. Based on the results of the Determination Coefficient test, the value of Adjusted R Square (R2) is $99.00 \%$, this means that the amount of Return on Assets can be influenced and explained by the variables CAR, KAP, BOPO, and FDR, while the remaining $1 \%$ is explained by variables not examined in this study.
\end{abstract}

Keywords: Multiple Linear Regression; CAR; KAP; BOPO; FDR; ROA

\section{Pendahuluan}

Teknik Analisis dengan metode statistika sering dijumpai dalam penelitian yang menggunakan pendekatan kuntitatif. Hal ini merupakan suatu solusi agar peneliti dapat memperoleh hasil yang terukur dan kesimpulan dari penelitian tersebut. Salah satu metode statistika yang dapat digunakan dalam menganalisis data kuantitatif adalah analisis regresi. Analisis regresi merupakan salah satu metode analisis data yang digunakan untuk mengkaji hubungan antar variabel dependen dan independen untuk mendapatkan sebuah model, sehingga model tersebut dapat digunakan untuk memprediksi fenomena yang terjadi antara variabel tersebut.[1]. Dalam persamaan regresi hubungan 
antara variabel dependen dengan variabel independen dapat berbentuk linier dan non linier [2]. Bentuk umum model regresi adalah sebagai berikut:

$$
Y_{i}=f\left(\beta_{i}, X_{i}\right)+\varepsilon_{i}
$$

Dimana variabel dependen pada suatu pengamatan ke-i adalah yi, sedangkan variabel independen pada pengamatan ke-I adalah xi. $\beta$ adalah parameter, $\varepsilon_{i}$ merupakan residual pada pengamatan ke idengan asumsi identik independen and normal distribution (IIDN) $\left(0, \sigma^{2}\right)$ [3]. Dalam Penelitian ini menggunakan Multiple Linier regression atau (regresi linier berganda). Analisis regresi linier berganda merupakan pengembangan dari regresi sederhana, dimana dalam model regresi linier berganda terdapat variabel independen yang lebih dari satu variabel. Sehingga bentuk umum model regresi linier berganda adalah sebagai berikut:

$$
Y=\beta_{0}+\beta_{1} X_{1}+\beta_{2} X_{2}+\cdots+\beta_{k} X_{k}+\varepsilon
$$

Jika data yang digunakan adalah data sampel, maka model estimasi dari persamaan 2 adalah sebagai berikt:

$$
Y_{i}=\beta_{0}+\beta_{1} X_{1 i}+\beta_{2} X_{2 i}+\cdots+\beta_{k} X_{k i}+\varepsilon_{i}
$$

Sesuai dengan persamaan 3 maka analisis regresi linier berganda dapat digunakan untuk memprediksi nilai dari suatu variabel dependen $(y)$ berdasarkan nilai dari variabel independen $\left(x_{1}, x_{2}\right.$, $\left.\ldots, x_{i}\right)$ melihat pengaruh sejumlah variabel independen $\left(x_{1}, x_{2}, \ldots, x_{i}\right)$ terhadap variabel dependen $(y)$.

Model Regresi linier berganda dapat digunakan dalam memodelkan kinerja suatu bankan, Salah satunya adalah kinerja keuangan. Kinerja keuangan suatu bank dapat diukur dengan mengunakan Laporan Keuangan. Berdasarkan Annual report bank Muamalah tahun 2013 sampai dengan tahun 2019. Total Aset Bank Muamalah mengalami fluktuaktif dengan penurunan nilai asset tahun 2015,2016,2018 dan 2019 yang penurunannya di sebabkan oleh turunnya menurunnya posisi Dana Pihak Ketiga, turunnya Investasi pada Surat Berharga dan Giro pada Bank Lain. Tingkat profitabilitas Bank Muamalat Indonesia yang dinilai dengan Return On Asset menunjukkan penurunan berturutturut dimulai tahun 2016 sebesar 22\%, pada tahun 2017 menurun menurun menjadi 11\%. Kemudian nilai ROA kembali menurun pada tahun 2018 menjadi $0.08 \%$ dan puncaknya pada tahun 2019 Roa menjadi $0,05 \%$. Artinya bank tidak dapat memaksimalkan asset-asetnya setiap tahun, sehingga profitabilitas terus menurun.

Penelitian mengenai Kinerja Keuangan dengan menggunakan metode regresi linier berganda pernah dilakukan oleh Dewa dan Ida dengan menggunakan variabel CAR, NPL dan LDR untuk mengukur ROA, [4] Devi dan Ahmad pada tahun 2018 pengaruh NPF, CAR, ROA, DPK terhadap penyaluran pembiayaan bank syariah [5]. Tujuan dari penelitian ini adalah mengetahui Pengaruh Capital Adequacy Ratio (CAR), Kualitas Aktiva Produktif (KAP), Beban Operasional terhadap Pendapatan Operasional (BOPO), dan Financing to Deposit Ratio (FDR) Terhadap Return On Assets (ROA) Pada PT. Bank Muamalat Indonesia Tbk

\section{Metode Penelitian}

Jenis penelitian yang digunakan dalam penelitian ini adalah penelitian terapan (Applied resaearch) yakni penelitian dengan menggunakan dan mengembangkan keilmuan dengan teori statistik yang diaplikasikan dalam bidang perbankan. Penelitian ini dilakukan di Laboratorium perbankan IAIN Sultan Amai Gorontalo dari bulan oktober sampai dengan bulan november tahun 2020, dengan cara mengakses website resmi PT Bank Muamalat Indonesia Tbk.

Data yang digunakan dalam penelitian ini adalah data dari laporan keuangan PT Bank Muamalat Indonesia Tbk. Data didapatkan dengan pengumpulan data sekunder yang berasal dari laporan triwulan PT. Bank Muamalat Indonesia dan Otoritas Jasa Keuangan (OJK) periode 20132020 kuarter II.

\subsection{Variabel Penelitian}


Variabel yang digunakan dalam penelitian ini terdiri dari variabel dependen yakni Return On Assets (ROA) dan Variabel independen adalah (Capital Adequacy Ratio (CAR) (X1), Kualitas Aktiva Produktif (KAP) (X2), Beban Operasional terhadap Pendapatan Operasional (BOPO) (X3), dan Financing to Deposit Ratio (FDR) (X4).

1. Capital Adequacy Ratio (CAR)

CAR merupakan perbandingan modal bank dengan Aktiva Tertimbang Menurut Resiko. Semakin tinggi rasio CAR mengindikasikan bank tersebut semakin sehat permodalannya. Rumus menghitung CAR adalah:

$C A R=\frac{\text { Modal }}{\text { Aktiva Tertimbang Menurut Resiko }} \times 100 \%$

2. Kualitas Aktiva Produktif (KAP)

Aktiva produktif adalah kemampuan bank untuk mengelola dana sesuai dengan fungsinya. Pengukuran kualitasnya yaitu dengan membandingkan APYD yang diberikan dengan total aktiva produktif.

$$
K A P=\frac{\text { Aktiva Produktif yang Diklasifikasikan }}{\text { Total Aktiva Produktif }} \times 100 \%
$$

3. Beban Operasional terhadap Pendapatan Operasional (BOPO)

Rasio Biaya Operasional Per Pendapatan Operasional (BOPO) digunakan untuk mengukur tingkat efisiensi dan kemampuan bank dalam melakukan kegiatan operasinya. Rumus BOPO dapat dihitung:

$$
B O P O=\frac{\text { Total Beban Operasional }}{\text { Total Pendapatan Operasional }} \times 100 \%
$$

4. Financing to Deposit Ratio (FDR)

FDR adalah rasio untuk mengukur seberapa jauh kemampuan sendiri dengan mengandalkan kredit yang telah didistribusikan ke masyarakat. Rumus menghitung FDR adalah:

$$
F D R=\frac{\text { Total Pembiayaan }}{\text { Total dana Pihak Ketiga }} \times 100 \%
$$

5. Return on Assets (ROA)

Return on Asset (ROA) adalah rasio yang menggambarkan kemampuan bank dalam mengelola dana yang diinvestasikan dalam keseluruhan aktiva yang menghasilkan keuntungan. Rumus ROA dapat dihitung:

$$
\text { ROA }=\frac{\text { Laba Sebelum Pajak }}{\text { Total Aset }} \times 100 \%
$$

\subsection{Asumsi Klasik}

Secara teoritis penggunaan analisis regresi linier berganda akan menghasilkan nilai estimasi parameter yang valid bila terpenuhinya asumsi klasik, Menurut [6] Asumsi klasik untuk regrsi berganda adalah sebagai beriku:

\section{Uji Normalitas}

Uji Normalitas bertujuan untuk menguji apakah dalam model regresi variabel terikat dan variabel bebas mempunyai distribusi normal atau tidak, nilai residualnya mempunyai distribusi normal atau tidak. Model regresi yang baik adalah memiliki nilai residual normal atau mendekati normal. Uji normalitas yang digunakan dalam penelitian ini adalah Kolmogorov Smirnov yaitu dengan kriteria jika signifikan Kolmogorov Smirnov $<0.05$ maka data tidak normal, sebaliknya jika signifikan Kolmogorov Smirnov $>0.05$ maka data normal. 


\section{Uji Multikolinieritas}

Uji Multikolinieritas bertujuan untuk menguji apakah didalam model regresi ditemukan adanya korelasi antara variabel bebas. Model regresi yang baik seharusnya tidak terjadi korelasi diantara variabel bebas. Untuk mendektesi Multikolinearitas didalam regresi dapat dilihat dari nilai Variance inflation factor (VIF) dan nilai tolerance. Jika VIF $<10$ dan tolerance $>0,1$ maka tidak terjadi Multikolinearitas, tetapi jika VIF $>10$ dan tolerance $>0,1$ maka terjadi Multikolinearitas.

\section{Uji Heteroskedastisitas}

Uji heteroskedastisitas bertujuan untuk melihat apakah dalam model regresi terjadi ketidaksamaan varian residual satu pengamatan ke pengamatan lain. Jika residual satu pengamatan ke pengamatan lain tetap, maka disebut homokedasitas dan jika berbeda disebut heteroskedastisitas. Model regresi yang baik adalah yang homokedastisitas atau yang tidak terjadi heteroskedastitas. Untuk mendeteksi adanya heteroskedastisitas dapat menggunakan uji glejser. Dalam uji ini, apabila hasilnya sig $>0,05$ maka tidak terdapat gejala heterokedastisitas, model yang baik jika tidak terjadi heterokedastisitas.

\section{Uji Autokorelasi}

Uji auokorelasi bertujuan untuk menguji apakah dalam model regresi linier ada korelasi antara kesalahan pengganggu pada periode $\mathrm{t}$ dengan pengganggu pada periode $\mathrm{t}-1$ (waktu sebelumnya), Untuk mendeteksi ada atau tidaknya autokorelasi, dalam penelitian ini menggunakan metode uji Durbin-Watson. Kriteria pengujiannya ialah jika nilai hitung durbin Watson (d) kurang dari nilai tabel durbin Watson pada signifikasi 0,05 dengan meperhatikan jumlah variabel independent dan jumlah sampel. Jika nilai d lebih dari (dU) dan kurang dari (4-dU) Maka dapat disimpulkan bahwa tidak terjadi pelanggaran asumsi autokorelasi

\subsection{Analisis Regresi Linier Berganda}

Analisis regresi digunakan untuk melihat pengaruh variabel independen terhadap variabel dependen dan menggunakan variabel independen untuk memprediksi nilai variabel dependen. Persamaan regresi linier berganda adalah model persamaan regresi linier dengan variabel bebas lebih dari satu. Dapat ditentukan persamaan regresi linier berganda penelitian ini sebagai berikut:

$\mathrm{Y}=$ Return on Asset (ROA)

$\alpha=$ Konstanta

$\mathrm{X}_{1}=$ Capital Adequacy Ratio (CAR)

$\mathrm{X}_{2}=$ Kualitas Aktiva Produktif (KAP)

$\mathrm{X}_{3}=$ Beban Operasional Terhadap Pendapatan Operasional (BOPO)

$\mathrm{X}_{4}=$ Financing to Deposit Ratio (FDR)

$\beta_{1}, \beta_{2}, \beta_{3}, \beta 4,=$ Koefisien Regresi

$\mathrm{E}=$ error

\subsection{Pengujian Hipotesis}

Uji hipotesis dalam penelitian ini menggunakan uji regresi linear berganda, Untuk menguji hipotesis pengaruh Capital Adequacy Ratio (CAR), Kualitas Aktiva Produktif (KAP), Beban Operasional Terhadap Pendapatan Operasional (BOPO) dan Financing to Deposit Ratio (FDR) Terhadap Return on Asset (ROA). Dalam pengujian ini menggunakan uji t dan uji F.

Uji T digunakan untuk melihat pengaruh variabel Independen terhadap variable dependent secara parsial dengan membandingkan nilai thitung dengan $\mathrm{t}$ tabel, dan membandingkan nilai $p$-value 
dengan nilai signifikansi $\alpha(0,05)$, dengan kriteria pengujian, Tolak $\mathrm{H}_{0}$ jika nilai $t_{\text {hitung }}>\mathrm{t}_{\text {tabel }}$ dan nilai p-value $<$ nilai sig. $(0,05)$

Uji $\mathrm{F}$ digunakan untuk melihat pengaruh variabel Independen terhadap variable dependent secara simultan dengan membandingkan nilai $\mathrm{F}$ hitung dengan $\mathrm{F}$ tabel, dan membandingkan nilai $p$ value dengan nilai signifikansi $\alpha(0,05)$, dengan kriteria pengujian, Tolak $\mathrm{H}_{0}$ jika nilai $\mathrm{t}_{\text {hitung }}>\mathrm{t}_{\text {tabel }}$ dan nilai p-value $<$ nilai sig. $(0,05)[7]$.

\subsection{Koefisien Determinasi}

Uji koefisien determinasi bertujuan untuk mengetahui seberapa besar kemampuan variabel independen menjelaskan variabel dependen. Besarnya koefisien determinasi dinyatakan dalam persentase yang nilainya berkisar 0 sampai dengan 1. Jika nilai koefisien determinasi semakin mendekati angka nol maka semakin kecil pula akan berpengaruh semua variabel independen terhadap nilai variabel dependen. Sedangkan Jika nilai koefisien determinasi semakin mendekati 1 maka dapat dikatakan semakin kuat model tersebut dalam menerangkan variasi variabel independen terhadap variabel dependen [1].

\section{Hasil dan Pembahasan}

\subsection{Deskriptif statistik}

Dalam penelitian ini menggunakan data rasio dari Return On Assets (ROA), Capital Adequacy Ratio (CAR) (X1), Kualitas Aktiva Produktif (KAP) (X2), Beban Operasional terhadap Pendapatan Operasional (BOPO) (X3), dan Financing to Deposit Ratio (FDR) (X4). Karena data dalam penelitin ini menggunakan data dengan skla rasio maka deskrisi statistik yang dilihat adalah nilai minimum, nilai maximum, mean (rata-rata) dan standar deviasi dari masing-masing variabel penelitian.

Tabel 1. Deskriptive statistics

\begin{tabular}{crrrrr}
\hline Variabel & Minimum & Maksimum & Mean & Std. Deviation & Variance \\
\hline Y & 0.02 & 1.72 & 0.4457 & 0.56174 & 0.316 \\
X1 & 10.16 & 17.61 & 13.278 & 1.716 & 2.944 \\
X2 & 0.32 & 6.54 & 3.158 & 1.587 & 2.518 \\
X3 & 82.07 & 99.90 & 94.857 & 5.642 & 31.836 \\
X4 & 68.05 & 106.50 & 89.030 & 11.689 & 136.632 \\
\hline
\end{tabular}

\subsection{Pengujian Asumsi Klasik}

\subsubsection{Uji Asumsi Normalitas}

Berdasarkan hasil pengujian normalitas dengan menggunakan kolomogorof simirnov, diperoleh nilai yang disajikan pada Tabel 2.

Tabel 2. Uji Normalitas

\begin{tabular}{lllll}
\hline \multirow{2}{*}{ Kelas } & \multicolumn{2}{l}{ Kolmogorov-Smirnov ${ }^{\mathrm{a}}$} & \multirow{2}{*}{ Keterangan } \\
\hline $\begin{array}{l}\text { Unstandardized } \\
\text { Residual }\end{array}$ & .705 & 30 & .703 & $\begin{array}{l}\text { Berdistribusi } \\
\text { Normal }\end{array}$ \\
\hline
\end{tabular}

Sumber: Output SPSS 20

Pada tabel Test of Normality, untuk Unstandardized Residual dapat dilihat nilai Sig. pada kolom Kolmogorov-Smirnov adalah .0,703 Sehingga sesuai dengan kriteria pengujian, jika nilai Sig. lebih dari 0,05 maka gagal tolak $\mathrm{H}_{0}$. Ini artinya data yang yang digunakan berdistribusi secara normal. 


\subsubsection{Uji Asumsi Multikolinieritas}

Berdasarkan hasil pengujian dengan menggunakan IBM SPSS 20 diperoleh bahwa nilai dari collinearity statistics seperti pada Tabel 3.

Tabel 3. Hasil Uji Multikolinieritas

\begin{tabular}{|c|c|c|c|}
\hline \multirow{2}{*}{ Model } & \multicolumn{2}{|c|}{ Collinearity Statistics } & \multirow{2}{*}{ Keterangan } \\
\hline & Tolerance & VIF & \\
\hline CAR & 0.660 & 1.516 & Tidak ada multikolinieritas \\
\hline KAP & 0.344 & 2.905 & Tidak ada multikolinieritas \\
\hline BOPO & 0.270 & 3.709 & Tidak ada multikolinieritas \\
\hline FDR & 0.488 & 2.051 & Tidak ada multikolinieritas \\
\hline
\end{tabular}

Sumber: Output SPSS 20

Berdasarkan Tabel 3 diperoleh bahwa nilai Tolerance dari masing-masing variabel independen berada di atas 0,1 . Demikian juga nilai dari VIF dari masing masing variabel independen kurang dari 10. Dimana untuk CAR mempunyai nilai tolerance 0,660 dan VIF sebesar 1,516, KAP mempunyai nilai tolerance 0,344 dan VIF sebesar 2.905, dan BOPO mempunyai nilai tolerance 0,270 dan VIF sebesar 3.709. serta FDR mempunyai nilai tolerance 0,488 dan VIF sebesar 2.051. Hal ini menunjukkan tidak adanya korelasi antara sesama variabel bebas dalam model regresi dan dapat disimpulkan bahwa tidak terdapat masalah multikolinearitas diantara sesama variabel bebas dalam model regresi yang dibentuk

\subsubsection{Uji Asumsi Heteroskedastisitas}

Berdasarkan hasil pengujian dengan menggunakan IBM SPSS 20 diperoleh bahwa nilai hasil uji heteroskedastisitas seperti pada Tabel 4.

Tabel 4. Hasil Uji Heteroskedastisitas

\begin{tabular}{|c|c|c|c|}
\hline Variabel Independen & $\begin{array}{l}\text { Koefisien } \\
\text { regresi }(\beta)\end{array}$ & t-hitung & Signifikan (t) \\
\hline CAR & 0.006 & 1.710 & 0.100 \\
\hline KAP & 0.006 & 1.124 & 0.272 \\
\hline BOPO & -0.001 & -0.525 & 0.604 \\
\hline FDR & -0.002 & -2.395 & 0.024 \\
\hline
\end{tabular}

Sumber: Output SPSS 20

Berdasakan hasil pada Tabel 4 diperoleh bahwa nilai signifikan dari variabel independen lebih besar dari 0,05 dimana untuk CAR didapatkan nilai signifikan 0,100, untuk variabel KAP didapatkan nilai signifikansi sebesar 0,272, demikian juga dengan BOPO diperoleh nilai signifikan sebesar 0,604 Hal ini menunjukan bahwa variabel independen (CAR, KAP dan BOPO) tidak ada yang signifikan secara statistic dalam mempengaruhi variabel dependen nilai absolute unstandardized residual (Absu). Sehingga dapat disimpulkan bahwa ketiga variabel independent terebut tidak terjadi gejala heteroskedastisitas. Berbeda dengan variabel FDR yang mendapatkan nilai signifikansi sebesar 0,024. Jika kita menggunakan nilai signifikan sebesar 0,05 maka terjadi pelanggaran asumsi heteroskedastisitas. Akan tetapi jika kita menggunakan taraf signifikan 0,01 atau 1\%, maka dapat dikatakan tidak terjadi pelanggaran asumsi heteroskedastisitas.

\subsubsection{Uji Asumsi Autokorelasi.}

Berdasarkan hasil pengujian dengan menggunakan IBM SPSS 20 diperoleh bahwa nilai durbin watson seperti pada Tabel 5. 
Tabel 5. Hasil Uji Autokorelasi dengan Durbin Watson

\begin{tabular}{ccccc}
\hline $\mathrm{R}$ & R Square & $\begin{array}{c}\text { Adjusted R } \\
\text { Square }\end{array}$ & $\begin{array}{c}\text { Std. Error of } \\
\text { the Estimate }\end{array}$ & $\begin{array}{c}\text { Durbin- } \\
\text { Watson }\end{array}$ \\
\hline 0.523 & 0.273 & .111 & 0.028 & 2.072 \\
\hline
\end{tabular}

Sumber: Output SPSS 20

Berdasarkan hasil pada tabel 5 diperoleh bahwa nilai Durbin-Watson adalah sebesar 2.072. Selanjutnya nilai tersebut kita dibandingkan dengan nilai tabel durbin Watson pada signifikansi 0,05 denagn $\mathrm{k}$ (jumlah variabel independent $)=4$ dan N (Jumlah Sampel) $=30$. Maka ditemukan bahwa nilai dL sebesar 1.1426 dan dU sebesar 1.7386. Sehingga nilai durbin-watson (d) sebesar 2.072 lebih besar dari (dU) yaitu 1.7386 dan kurang dari (4-dU) $4-1.7386=2,2614$. Maka sebagai dasar pengambilan keputusan dalam uji durbin Watson di atas maka dapat disimpulkan bahwa tidak terdapat pelanggaran asumsi autokorelasi. Dengan demikian analisisi regresi linier berganda dapat dilakukan.

\subsection{Pengujian Hipotesis}

Analisis statistic yang digunakan dalam penelitian ini adalah multiple regresi atau yang banyak dikenal dengan regresi linier berganda. Analisis ini digunakan untuk mengetahui besarnya pengaruh variabel independen yaitu CAR, KAP, BOPO, dan FDR terhadap variabel dependen yaitu ROA. Besarnya pengaruh dari variabel independen dengan dependen secara simultan dan juga secara parsial. Bedasakan hasil perhitungan dengan menggunkan bantuan software IBM SPSS 20 diperoleh hasil sebagai beriikut pada Tabel 6 .

Tabel 6. Hasil Analisis Regresi

\begin{tabular}{ccccc}
\hline Variabel Independen & $\mathrm{B}$ & $\mathrm{T}$ & Sig. t & Keterangan \\
\hline Konstanta & 9.084 & 23.283 & 0.000 & Signifikan \\
CAR & -0.003 & -0.339 & 0.738 & Tidak Signifikan \\
KAP & 0.012 & 1.104 & 0.280 & Tidak Signifikan \\
BOPO & -0.096 & -26.757 & 0.000 & Signifikan \\
FDR & 0.005 & 3.683 & 0.001 & Signifikan \\
\hline
\end{tabular}

Keterangan: $t$ tabel $=\mathrm{t}_{(30 ; 0,05)}=1,697$

Sumber: Output SPSS 20

Berdasarkan hasil rekapitulasi pada Tabel 6 maka dapat diketahui persamaan regresi adalah sebagai berikut:

$$
y=9,084-0,003 X_{1}+0,012 X_{2}-0,096 X_{3}+0,005 X_{4}
$$

Interpretasi model regresi adalah sebagai berikut:

1. Nilai Konstanta sebesar 9,084 mengindikasikan bahwa jika variabel independen yaitu CAR, KAP, BOPO, dan FDR bernilai nol maka ROA sebesar 9,084.

2. Variabel CAR berpengaruh negative terhadap ROA, tetapi tidak berpengaruh secara signifikan. Hal ini ditunjukan oleh nilai probabilitas signifikansi Sig. $>\alpha$ yaitu $0,738>0,05$ yang menunjukan bahwa gagal tolak H0. Karena koefisien dari variabel CAR bernilai negatif yaitu $-0,003$, maka hal ini mengindikasikan bawah setiap peningkatan satu satuan pada CAR akan mengakibatkan pengurangan ROA sebesar 0,003 satuan dengan asumsi variabel lain konstanta. Sehingga dapat disimpulkan bahwa variabel CAR berpengaruh negatif dan tidak signifikan terhadap ROA.

3. Variabel KAP berpengaruh positif terhadap ROA, dan tidak berpengaruh secara signifikan. Hal ini ditunjukan oleh nilai probabilitas signifikansi Sig. $>\alpha$ yaitu $0,280>0,05$ yang menunjukan bahwa gagal tolak H0. Karena koefisien dari variabel KAP bernilai positif yaitu 0,012, maka hal ini mengindikasikan bawah setiap peningkatan satu satuan terhadap KAP 
akan mengakibatkan peningkatan ROA sebesar 0,012 satuan dengan asumsi variabel lain konstanta. Sehingga dapat disimpulkan bahwa variabel KAP berpengaruh positif terhadap ROA.

4. Variabel BOPO berpengaruh negatif dan signifikan terhadap ROA, Hal ini ditunjukan oleh nilai probabilitas signifikansi Sig. $>\alpha$ yaitu $0,000<0,05$ yang menunjukan bahwa tolak $\mathrm{H} 0$. Karena koefisien dari variabel BOPO bernilai negatif yaitu -0,096, maka hal ini mengindikasikan bawah setiap peningkatan satu satuan BOPO akan mengakibatkan penurunan ROA sebesar 0,095 satuan dengan asumsi variabel lain konstanta. Sehingga dapat disimpulkan bahwa variabel BOPO berpengaruh negatif terhadap ROA.

5. Variabel FDR berpengaruh positif dan signifikan terhadap ROA. Hal ini ditunjukan oleh nilai probabilitas signifikansi Sig. $>\alpha$ yaitu $0,001<0,05$ yang menunjukan bahwa tolak H0. Karena koefisien dari variabel FDR bernilai positif yaitu 0,005, maka hal ini mengindikasikan bawah setiap peningkatan satu satuan FDR akan mengakibatkan peningkatan ROA sebesar 0,005 satuan dengan asumsi variabel lain konstanta. Sehingga dapat disimpulkan bahwa variabel FDR berpengaruh positif terhadap ROA.

Dari keempat variabel yang digunakan untuk mengukur ROA maka di peroleh bahwa BOPO merupakan variabel yang paling berpengaruh terhadap ROA, karena memperoleh konstanta sebesar -0,096, akan tetapi pengaruhnya negatif, kemudian KAP sebesar 0,012 dan FDR sebesar 0,005. Serta variabel CAR yang berpengaruh negatif sebesar 0,003 terhadap ROA

Uji statistik F pada dasarnya menunjukkan apakah semua variabel bebas dimasukkan dalam model mempunyai pengaruh secara bersama-sama terhadap variabel terikat. Untuk mengetahui apakah model regresi yang digunakan merupakan model tetap (fixed model) dapat dilakukan dengan membandingkan nilai $\mathrm{F}$ tabel dan $\mathrm{F}$ hitung atau membandingkan antara nilai sig dan $\alpha=0,05$.

Berdasarkan hasil perhitungan dengan menggunakan aplikasi IBM SPSS 20 di peroleh hasil uji simultan yang disajikan pada Tabel 7 .

Tabel 7. Hasil Uji F

\begin{tabular}{|c|c|c|c|c|c|}
\hline Model & Sum of Squares & Df & Mean Square & $\mathrm{F}$ & Sig. \\
\hline Regression & 9.072 & 4 & 2.268 & 714.393 & $.000^{\mathrm{b}}$ \\
\hline Residual & 0.079 & 25 & 0.003 & & \\
\hline Total & 9.151 & 29 & & & \\
\hline
\end{tabular}

Nilai $F$ tabel untuk $n=30$ pada $\alpha=0,05$ adalah 2,55. Nilai $F$ hitung yaitu 714.393dengan nilai signifikansi yaitu $0,000<0.05$. Hal ini menunjukan bahwa variabel independen (CAR, KAP, BOPO dan FDR) berpengaruh secara bersama-sama atau simultan terhadap variabel dependen (ROA).

\subsection{Koefisien Determinasi}

Analisis koefisien determinasi digunakan untuk mengetahui persentase variasi variabel bebas yang digunakan dalam model mampu menjelaskan variasi variabel terikat. Hasil analisis determinasi dapat dilihat pada output model summary dari hasil analisis regresi berganda, seperti pada Tabel 8 .

Tabel 8. Hasil Uji Koefisien Determinasi

\begin{tabular}{ccccc}
\hline $\mathrm{R}$ & $\begin{array}{l}\mathrm{R} \\
\text { Square }\end{array}$ & $\begin{array}{l}\text { Adjusted } \mathrm{R} \\
\text { Square }\end{array}$ & $\begin{array}{l}\text { Std. Error of the } \\
\text { Estimate }\end{array}$ \\
\hline 0.996 & 0.991 & 0.990 & & 0.05634 \\
\hline
\end{tabular}

Sumber: Output SPSS 20 
Berdasarkan hasil output pada tabel 4.12 diperoleh korelasi antara variabel independen terhadap variabel dependen sebesar sebesar 0,990 sebagai mana yang ditunjukan pada Adjusted R Square. Hal ini mengindikasikan bahwa kontribusi variabel CAR, KAP, BOPO dan FDR ROA adalah sebesar $99,00 \%$, sedangkan sisanya sebesar $1.00 \%$ dipengaruhi oleh variabel-variabel lain yang tidak digunakan dalam penelitian ini.

\section{Kesimpulan}

Secara parsial CAR dan KAP tidak berpengaruh secara signifikan terhadap Return On Assets, Sedangkan BOPO dan FDR secara parsial berpengaruh secara signifikan terhadap Return On Assets. Adapun secara simultan keempatt variable tersebut berpengaruh ignifikan terhadap Return On Assets pada PT Bank Muamalat Indonesia. Selanjutnya, berdasarkan hasil uji Koefisien Determinasi nilai Adjusted $R$ Square $\left(\mathrm{R}^{2}\right)$ adalah sebesar $99,00 \%$ hal ini berarti besarnya Return On Assets dapat dipengaruhi dan dijelaskan oleh variabel CAR, KAP, BOPO, dan FDR, sedangkan sebesar 1\% sisanya dijelaskan oleh variabel yang tidak diteliti dalam penelitian ini.

\section{Referensi}

[1] S. Ningsih and H. H. Dukalang, "Penerapan Metode Suksesif Interval pada Analsis Regresi Linier Berganda," Jambura J. Math., vol. 1, no. 1, pp. 43-53, Jan. 2019, doi: 10.34312/jjom.v1i1.1742.

[2] M.H. Kutner, C.J. Nachtsheim, and J. Neter, Applied Linear Regression Models, 4 th ed, New York: McGraw-Hill Companies, Inc. 2004.

[3] B. Green, and W. Silverman, Nonparametric Regression and Generalized Linear Models: A roughness penalty approach, United Kingdom: Taylor \& Francis, 1994.

[4] D. Ayu dan I. Bagus. "pengaruh rasio keuangan terhadap kinerja keuangan sektor perbankan di bursa efek Indonesia" E-Jurnal Akuntansi Universitas Udayana, vol. 14, no.2, Feb 2016.

[5] D. Permatasari dan A. R Yuliyanto "Analisis Kinerja Keuangan: Kemampuan Bank Syariah dalam Penyaluran Pembiayaan". Jurnal Akuntansi Indonesia, Vol. 7 No. 1, pp. 69-79, Jan. 2018.

[6] N.D. Gujarati, Basic Econometrics, 4 th ed, New York: McGraw - HillCompanies, Inc. 2003.

[7] I. Ghozali, Aplikasi Analisis Multivariate dengan Program SPSS, Semarang: Badan Penerbit Universitas Diponegoro, 2009. 